\title{
FISHING IN TROUBLED WATERS: DISQUETTES AND THIOFS IN DAKAR
}

\author{
Francis B. Nyamnjoh
}

The Economist of 17 January 2004 carried the following assessment: 'Sub-Saharan Africa ... is the world's poorest continent: half of its $700 \mathrm{~m}$ people subsist on 65 US cents or less a day. Even more worryingly, it is the only continent to have grown poorer in the past 25 years, despite the explosion of technology and trade that has boosted incomes in other regions. Not even Africans want to invest in Africa: an estimated $40 \%$ of the continent's privately held wealth is stashed offshore' (pp. 3-4). Economic problems have only worsened in recent times thanks to decades of stifling structural adjustment programmes facilitated by local dictatorships that have seldom hesitated to embezzle and bank abroad (Bayart et al. 1999; Mbaku 2004; Hope and Chikulo 2000; Nzongola-Ntalaja 2002).

Despite such bleakness and callous indifference, quite paradoxically, thanks to global consumer television, phenomenal advances in information and communication technologies, increased mobility and neo-liberal rhetoric, ordinary Africans have never been more bombarded by the allure of material abundance and infinite possibilities enticing them to join the consumer bandwagon. However, while advertisers might create the impression that availability is synonymous with affordability, the stark reality remains that of a bazaar to which 700 million are drawn but few rewarded with more than 65 US cents a day (Nyamnjoh 2004; van Binsbergen and van Dijk 2004; Mbaku and Saxena 2004). As some disappointed by exclusionary consumerism might seek refuge in fundamentalisms (cultural, religious and otherwise) of their own - even with ambiguous and contested outcomes (cf. Masquelier 2004 ) - others simply refuse to yield to easy exclusion and are ready to sacrifice anything, including morality, dignity and ultimately even their humanity, just to be consumer gatecrashers and zombies (cf. Nyamnjoh 2003). Such alternative trajectories are many and varied, ranging from accelerated embezzlement to accelerated fraud schemes - e.g. the Nigerian '419' (cf. Apter 1999) and Cameroonian Feymania (Malaquais 2001 ) - through the accelerated commoditization of sex and, in certain instances, of marriage. The youth, often frustrated by the power without responsibility of state, parents and the older generations, are easy prey to the generalized promiscuity engendered by poverty and

Francis B. Nyamnjoh is Associate Professor and Head of Publications and Dissemination with the Council for the Development of Social Science Research in Africa (CODESRIA). He has taught sociology, anthropology and communication studies at universities in Cameroon, Botswana and South Africa, and has researched and written extensively on Cameroon and Botswana, where he was awarded the Senior Arts Researcher of the Year prize for 2003. His most recent books include Africa's Media, Democracy and the Politics of Belonging (Zed Books, 2005). 
beleaguered desire (Mbembe 1985: 133-42; Cole 2004b). The uncertainty of consumption under the canopy of chronic poverty and sterile repression unleashes fierce competition even amongst those scavenging for sustenance in refuse dumps.

A consequence of such desperation and stubborn determination to belong is that throughout Africa accelerated consumerism is producing consumers without affordability and affordability without the typical signs of effort. Everyone seems gripped by 'the allure of accruing wealth from nothing' or of spending without earning, as 'the will to consume outstrips the opportunity to earn' (Comaroff and Comaroff 2000:313-17). Selling adults and children into slavery and prosititution, ${ }^{1}$ migrating in search of greener pastures as labour zombies (cf. Morris and Bouillon 2001; Buggenhagen 2003) and seeking magical solutions to material predicaments (Moore and Sanders 2001) are increasingly attractive options for increasingly desperate Africans. Accelerated consumerism is radically redefining relations of power and value in ways that celebrate opportunism and greed, that heighten the uncertainties in African lives and dramatize the helplessness of those at the margins of consumer power and success. It is also cultivating a sterile desire to crave, since it succeeds in bringing its converts to see consumption as the sole indicator of existence and achievement. Love for the sake of love, if ever there were such an illusion, is fast ceding terrain to calculated mercantilism in the suicidal pursuit of material comforts (Cole 2004a, 2004b; Haram 2004; Buggenhagen 2003). ${ }^{2}$ In matters of sex, first-rate consumption means going for the juiciest and rarest, which for older men and women entails shopping down the generational ladder (right into paedophilia) for power, status and privilege. For the younger generations, it means shopping up (among sugar daddies, sugar mummies, businessmen and women, whites, tourists and others) for consumer opportunities and consumer citizenship. The current context of acute poverty, interlinked with dramatic and luring images of desire and abundance, has accelerated the commoditization of sex in Africa, putting morality and God on hold as money and survival take centre stage.

The timing of this acceleration is unfortunate for a continent of vulnerabilities and of people doubly victimized by the insensitivities of power without responsibility (cf. The Economist 2004: 1-16) and of the dominant tendency to privilege 'profit over people' (Chomsky 1999). In connivance with consumerism, HIV/AIDS poses an extra threat to Africa as the 'scar on the conscience of the world', ${ }^{3}$ by turning the continent into a festering sore with little chance of healing. 'All of Africa's famines are now AIDS-related: hungry people lack the strength to fight off sickness, sick people lack the strength to grow food, and dead

\footnotetext{
${ }^{1}$ See <http://newsvote.bbc.co.uk/1/hi/world/africa/3653737.stm> (April 2004).

2 This is a theme extensively covered in popular urban folklore and fiction throughout Africa, and also by the booming Nigerian film industry.

${ }^{3}$ The words of British Prime Minister, Tony Blair, who created an Africa Commission to help 'resuscitate' the continent. See <http://news.bbc.co.uk/2/hi/uk_news/politics/ 3492232.stm>.
} 
parents cannot teach their children how to farm' (The Economist 2004: 13). Although 'the price of AIDS drugs has plummeted by more than $95 \%$ in the past few years', with middle-income countries such as South Africa and Botswana being able to fund their own drugs programmes, the rest of Africa is simply too poor to keep hope alive for more than an elite few. And 'the worst is yet to come' (ibid.).

Making a creed of greed can only worsen matters (cf. Sekoni 1997). The unchecked pursuit of consumerism enhances self-seeking individuals at the expense of family and community. The power and opportunities consumerism brings are limited to a minute few - those with greed and means enough to indulge themselves with impunity. Even with them, success is merely an illusion because consumer capitalism brings with it seemingly eternal cycles of indebtedness, manipulation, zombification and the never-ending search for fulfilment. The appetites it generates only grow stronger and those who yield to their allure are instantly trapped and ultimately consumed, but not before consuming their own (and others') sociality and - in conjunction with HIV/AIDS - humanity. Consumerism thus serves as a foil for the moral community of Africans, offering little more than multiple dimensions of dying, even to its most ardent disciples.

Of the three countries where I have investigated consumerism, especially amongst the youth, only one - Botswana - is among Africa's six upper middle-income countries. The two others, Cameroon and Senegal, are classified among thirty-eight low-income countries (cf. $\mathrm{ADB}$ 2003). Some of the Cameroon research has been published as representations of whiteness and consumer opportunities by mainly university students (cf. Nyamnjoh and Page 2002) and serves as an interesting parallel to the current focus on the language of consumerism and commoditized sex in Dakar. As a low-income country where consumers are constrained by inter alia chronic poverty, Senegal - like Cameroon-offers a fascinating setting to observe how ordinary Africans seek belonging as consumer gatecrashers and zombies.

Methodologically, the present paper did not attempt to generate 'hard data representative of all segments' of Senegalese society, obtained through surveys or 'fieldwork' conducted on pre-selected target populations in specific and specified field locations. While conventional studies might harbour such pretensions (with obvious potential benefits), not every subject matter can be adequately explored with the rigour of a sample survey. Subjective and intersubjective accounts sometimes say much more about a phenomenon than does a dull and phoney objectivity. As one often realizes in the course of research, not all that counts can be counted, and not all that can be counted counts. The ethnography used in this paper has been harvested as I went along, propelled by a fascination with the theme in question and a background of similar interests pursued among students and youth elsewhere in Cameroon and Botswana. Over twenty-five years of research have taught me this: if you are passionate about a theme and have a way with people, rich ethnographic insights flow your way through interactions with others anywhere, anytime. One is always 
doing fieldwork, even when not formally in the field. While confining social research to formal field situations might yield 'hard facts', it detracts from those realities that may not immediately fit our practised instruments and scholarly manière de faire.

The data used in this paper thus result from a multiplicity of intersubjective encounters, ranging from personal experiences, through interviews and intensive conversations, with students (mostly university and high school) and non-students (maids, nightclubbers, beachcombers, shop assistants, bartenders, receptionists, waiters and waitresses, etc.) in different locations, to exchanges with others (market women, street hawkers, passengers in buses, taxi drivers, beggars on the streets, expatriates, visitors, as well as Senegalese and non-Senegalese colleagues at work, conferences, restaurants and other forums) on the various concepts and issues articulated herein. Other sources have included newspapers and magazines, popular music, Senegalese websites, related studies and, most importantly, the comments of scholars and colleagues in Senegal and elsewhere on earlier drafts of this paper. ${ }^{4}$

Senegal, a predominantly heterogeneous Muslim community 'fractured' by competing orders, is remarkable in the conviviality and connivance it forges between political and religious authorities, and between Western-educated intellectuals and Arabic-educated Islamists, despite their apparently different emphasis on what forms of knowledge, education and value systems should prevail (cf. Dilley 2004). Faced with the exigencies of the Western-educated urban elite in particular, Senegalese Islam has had, increasingly, to create room for or turn a blind eye to the sort of consumerism and permissiveness that comes with a bourgeoisie to whom religion and God, to be meaningful, must not stand in the way of earthly pleasures. Since colonial times, a certain elite, epitomized by the jazz-loving trendy évolué known generally as 'le sassouman', has always found space to indulge in 'modern pleasures' while paying lip-service to tradition and religious values (cf. Biaya 2001 ). With accelerated consumerism and compounding poverty, these tendencies are all the more noticeable, especially among urbanites, with or without remittances from the diasporic Murid 'transnational trader at the crossroads of heaven and earth, where profits meet prophets, prayers meet prosperity and the divine encounters the domestic' (Buggenhagen 2003: 14-37). Using the example of the language of consumerism, commoditized sex and sexified commodities in Dakar, this paper opens

\footnotetext{
${ }^{4}$ Among others, I would particularly like to thank the two anonymous reviewers for Africa, Fatou Sow, Amadou Fofana, Ebrima Sall, Evelyne Change, Eileen Julien, Signe Arnfeld, Jennifer Cole, Michael Ralph, Rekopantswe Mate, Urusaro Karekezi, Jane Agbu, Johanna Schoss, Mieka Ritsema, Andrea Swalec, Sheila Bunware, Barry Riddell, Roland Marchal, Martin Klein, Jim Ferguson, Paul Zeleza, Dickson Eyoh, Elisio Macamo, Chachage Chachage, Lucien Mufor Atanga, Jude Fokwang, Sanya Osha, Jeff Lever, Fred Hendricks, Amber Babke Gemmeke, Marie Ndiaye, Khary Fall Cisse, Houraye Mamadou Anne, Chifaou Amzat, Emiliane Faye, Jean Pierre Diouf, Virginie Niang, Francine Adade, Mohamed Cherif Diarra and other colleagues at CODESRIA in Dakar.
} 
a window onto the intricate world of Africans as real or potential consumer zombies trapped in acute poverty, competing bazaars of trivialization and commoditization, and the frightening consequences of consumer sex in a context of misguided generosities and hospitalities.

\section{THE CONCEPTS OF DISQUETTE AND DIRIYANKE}

In Dakar, if you eat out, frequent bars, hotels, casinos, nightclubs or the beach, if you are familiar with the world of school and university students, and if you are used to taking cars rapides ${ }^{5}$ or taxis, or to visiting cybercafés and cabines téléphoniques, you are most likely to understand what Dakarois mean by disquette and thiof. The two are most often to be seen together in these locations, sampling consumer goods and services. If in addition you have been shopping at popular markets such as Sandaga, Tilene, Colobane, and especially HLM, where African fabrics and dresses are made and sold in bulk, or if you are familiar with the various fish markets - the Marché Central au Poisson in particular - then you are likely as well to have heard the terms diriyanke and yaboy. These notions are common currency in various locations and have aroused my curiosity as a visiting sociologist.

Upon my very first visit to Dakar in November 2001, I immediately became interested in knowing more about why young, trendy, modern girls were called disquettes, as I had heard was the case. ${ }^{6}$ I was struck by the widespread usage of this metaphor, which may have originated in reference to slender, elegant, educated, trendy, beauty-conscious, fun-loving, nightclubbing, often young, girls fascinated by Western consumer tastes, music and the modern tunes of rising Senegalese stars. Dakarois generally trace the origin of disquette to the 1980 s when disco music was most popular amongst the young and when trendy teenagers would flood the nightclubs to have a good time in a modern way. It was a concept that drew from, complemented or opposed another, disco, used in reference to young men with a similar penchant for modern music and nightclubbing. In their fashionable, tight-fitting worn-out jeans, short skirts, blouses and with conspicuously displayed mobile phones, disquettes are perceived to be antonyms to diriyanke (see below). The 1980 s are generally considered to have marked the acceleration of 'cultural decadence' or the 'subversion of values' such as morality, sexual discipline and respect for maraboutic ideologies. Nightclubs, hotels, casinos, cinemas, video shops, restaurants, dibiteries and other fast food outlets, tourism and exhibitionism mushroomed as 'modern pleasure spaces' that appealed to the youth, inviting them to partake of a consumerism premised on phallic dominance by the crystallizing postcolonial bourgeoisie. By 1996, the decadence was so entrenched that Youssou N'Dour composed 'Birima', a song in which he castigated

\footnotetext{
${ }^{5}$ Privately owned and often battered public transport buses.

${ }^{6}$ Disquette is also the standard French term for a computer floppy disk. See below (p. 311 ).
} 
a decadent consumerist bourgeoisie who spent their time drinking, hanging about and copulating, to the detriment of their political, social and religious values and responsibilities (cf. Biaya 2001: 74-7). In other words, the bourgeoisie had gone beyond the threshold of tolerance or teranga that underpins the connivance, complicity and conviviality between domesticated secular Western consumerism and customized Islamic religious values (cf. Dilley 2004; Buggenhagen 2003).

Diriyankes are normally bulkier, often heavily perfumed and incensed, jewelled (with earrings, chain necklaces, bracelets and rings on fingers and toes) and richly traditionally dressed women, sometimes divorced, but clearly much older and without the youthful succulence, exuberance and trendiness to make them compete for the attention of the legitimating gaze of the opulent and searching 'modern' male. Diriyanke might also refer to a woman who has had a child out of wedlock, which disqualifies her as diankh (virgin), as a disquette is usually imagined to be. Diriyankes are reputedly good at business, well-to-do and generally in a position to flatter younger men with gifts and money. They are also experts at the art of seduction, with an impressive mastery of the traditional kit for seduction and eroticism in Senegal: 'They know how to make their companion or husband vibrate with pleasure'. ${ }^{7}$ According to an informant (Amadu Fofana, a doctoral student at Wisconsin), diriyanke is a coinage from the reflexive Wolof verb direek $u$ ('to drag oneself'), the conjugated form of which is diri ('drag'), and from the American (English) word 'yankee'. He conjectured that at one point in time, Senegalese women probably developed the reputation of dragging themselves along majestically like dignified American ladies and, by implication, for seeking after any American male they could set eyes on. If this is true, then the diriyankes of today were the disquettes of yesteryear and were just as shaped by expectations of fulfilment from across the Atlantic as are today's disquettes. Others emphasize the Wolof radical diri ('to pull a load behind or to keep on a leash') and the Pulaar suffix yanke ('the person who') to give the meaning 'the woman who keeps others on a leash' (cf. Buggenhagen 2003: 233), which is quite significant since diriyankes are known to want to keep both men and creditors under control.

Regardless of all the anecdotal accounts of diriyankes, in popular imagination the word reflects the dignified, slow and gracious gait and middle-aged elegance of the Senegalese lady at her best. In other words, the diriyanke is a 'grande dame' and it is worth noting that, nowadays, the label also applies occasionally to men of the same age range as their women counterparts, who love to dress in fashionable, expensive 'traditional' outfits and who are equally concerned about their looks and gaits. According to Buggenhagen (ibid.), the diriyanke is sometimes guilty of 'borrowing for self-presentation' (puukare) as, 'wearing the latest fashionable cloth, supporting enormous amounts of jewelry, a European handbag and shoes', she often 'appears at feasts only to encounter her hairdresser, manicurist, tailor and cloth vendor reeling

\footnotetext{
${ }^{7}<$ http://www.lequotidien.sn/dossiers/article.CFM?article_id=148\&var_doss=27>
} 
in her line of credit'. In a recent article captioned 'C'est la saison des rondeurs ... vivent les fesses' ('the time of plumpness has come: long live buttocks'), Habibatou Gologo (2003: 27-9) celebrates plumpness as the ultimate symbol of African beauty and argues that African men (heads of state included) adore marrying chubby women, even if they love to sample disquettes on the side. Proof that the diriyanke epitomizes traditional indicators of beauty and elegance in Senegal is the annual contest for the election of the diongoma nationale. Known also as ' $l a$ beauté $X L^{\prime}$ ', the successful diongoma should be a diriyanke with the best to offer in 'attractive well-rounded bottoms and charming curves, gracious elegance, and mastery of housekeeping ... in a word, the ideal traditional Senegalese woman'. 8 The reason for launching the contest in 1992 was to challenge the 'Miss Senegal' contest, which did not take into account 'the real image of the Senegalese woman' as it tended to privilege the slim Barbie-like disquettes in their Western outfits and manières de faire. ${ }^{9}$ However, their different indicators of beauty notwithstanding, both contests fit into a male-dominated order that dictates which women shall be consumed by whom and in what way. As Habibatou Gologo (op. cit.: 28 ) observes, in a context of hybrid globalization, both contests satisfy the two consumer expectations represented in Senegal. Thus while the Miss Senegal ('la femme filiforme') hopefully proceeds to serve as a model abroad, the diongoma stays back to service local appetites for the national ideal ('fait figure d'effigie nationale').

Just as every category includes cases at the margins tinkering at the borders of belonging, so also do the categories of disquette and diriyanke. But such exceptions, far from redefining the mainstream, rather stress the importance of tempering essentialism about reality and identity. Hence one could be young, trendy, elegant and not disposed to commoditizing one's body; just as one could be elderly, respectful and enmeshed in culture and tradition without necessarily passing for a diriyanke. On the other hand, it is equally worth admitting that not all disquettes are necessarily young, virginal or financially dependent, since the emphasis is sometimes placed on how one looks, dresses and comports oneself in determining how one is labelled. 'On est disquette par rapport à la forme, pas au fond,' some girls and young women would say. ${ }^{10}$ In such rare situations, as a young, married, female secretary put it, 'a disquette is a young or old woman who is always well dressed - coquette - and who takes care of herself, not necessarily because she would like to be thiofed or kept, but because she likes to be beautiful. ${ }^{11}$ A fifty-year-old married woman, for example, who looks, behaves and enjoys tastes similar to those of a young woman could be

\footnotetext{
8 'Une chute de rein et des rondeurs avantageuses, élégante gracieuse, bonne maîtresse de maison, ... l'idéal de la femme traditionnelle sénégalaise.'

${ }^{9}<$ http://beaute.afrik.com/article.php3?id_article=59>. A similar contest in Abidjan, 'Miss Awoulaba', was started in 1999 to reward 'l'harmonie physique et le charme naturel, with an inclination for women with postérieurs proéminents' (Gologo 2003: 28).

10 'Being disquette is down to appearances, not substance'.

11 See p. 310.
} 
termed disquette by her relatives and friends without any negative connotation intended. Within the same logic of appearances, the slimmer, trendier and ageless an older woman is, the more likely she is to pass for a disquette. However, as another female informant in her late twenties stated emphatically, 'No matter how coquette and well dressed you are and no matter how slender, if you dress in traditional clothes, you are not a disquette, kept or not.' These differences in perception and opinion simply point to the fact that no structural reality is ever too essential to be redefined by the agency of the social actors living it. It also suggests there is something of a hierarchy involved in the way the two categories are constructed. Even though the disquette is the junior of the diriyanke, it seems as if the former has more social status or cultural capital, in a way, because of her proximity to foreign fashions and to the tastes and proclivities of those with money to spend.

Whether old or young, disquettes allegedly operate in a context of legendary hospitality, the famous teranga for which Senegal as a country is well renowned. They are also perceived, especially by moralizing men and women who either cannot afford them or are defending particular religious and cultural values, to be extremely risky and are likened to a millipede capable of wrong-footing anyone at any time ("les disquettes sont des millepattes, on ne sait jamais quelles pattes elles font marcher'). Yet there are some who believe that diriyanke are actually more risky when it comes to teranga. As a middle-aged, divorced single mother remarked, 'In a culture where sex is frowned upon outside wedlock, and where women can only leave home by getting married, diriyanke enjoy a certain freedom that eludes most disquettes. A divorced or widowed woman can choose not to return to her parents' or relatives' home and live alone without raising too much suspicion. A disquette who has never been married cannot escape scrutiny with such ease.' Given the symbolic centrality of marriage as a social institution in Senegal, any teranga by women is presumed to be ultimately about 'la recherche d'un mari' (the quest for a husband), even if at the end of the day, the husbands are not always worth women's while. A woman either in the quest for a husband or disappointed in one might look for a mbarane - a man she keeps on the side to cater for all kinds of needs (financial, sexual, affective or just a front) - and disquettes and diriyankes alike have been known to play the Robin Hood with the mbarane in favour of their regular partners or vice versa. Women whose husbands have migrated to seek greener pastures abroad find it difficult to be faithful and extra-marital relations are common, sometimes resulting in children who are not their husbands'. This sometimes ends in divorce, if the wives are not simply abandoned to themselves by husbands cutting off remittances as soon as they learn of the infidelity (cf. Buggenhagen 2003: 16)

This is how a single mother in her late twenties who has never married and who subscribes to being neither a disquette nor a diriyanke, captured these contradictions and changing times:

For a long time, Senegalese women have had only their charms as commodity. They had nothing to offer but their virginity, their body, their 
housekeeping expertise. And sex was considered pleasurable only to men and it was one of those things women used to get their husbands to do what they wanted. Nowadays, many women go for their own pleasure, and sex is not just something you do when you are married. Many women are not looking for a husband. They have been married or are widowed and do not want the kind of pressure a husband and a family-in-law put on a married woman. So many relationships are now based on how well people get along socially and sexually. These women are convenient to men because they often are independent financially and are not there for the money. More and more, young and not so young men go for these women.

While it is true that Senegalese and African women are increasingly demanding respect for their sexuality (cf. Arnfred 2004b), it is difficult to say how many of the unemployed women amongst them, who are finding it extremely difficult just to get by, can afford financial independence without the strings of super-exploitation and debasement. However, it is significant that younger women who do become financially independent refer to themselves or are labelled thiofettes, meaning a female thiof. Buggenhagen recounts the fascinating story of Jigeen, a Murid woman, who employs the assistance of local marabouts to 'attract money and influence people', and uses coquetry, sacrifice and ultimately marriage to a wealthy Murid trader to facilitate her migration to the USA to become a trader in her own right. This trajectory, Buggenhagen argues, is fairly common with older divorced women and women who have remained single into their thirties and forties, who are keen on financial autonomy and respect outside the pressures of conventional love and marriage (Buggenhagen 2003: 113-44).

Among urban youths, marriage is increasingly a case of ambivalence and vacillation, both because arranged marriages (especially to migrating males) by families targeting bridewealth payments threaten romantic love and personal autonomy among girls (cf. Buggenhagen op. cit.: 191-224), and because for many young men in a context of accelerated consumerism, coming by a faithful girlfriend whom one can eventually marry is very difficult (cf. Biaya 2001: 77-9). While young men 'bemoan the expansive and expensive demands of those they court', young women 'prize union with a migrant because it allows for more autonomy, the husband often being away, and the wife being able to put his remittances, which arrive monthly, for her own use', unlike bridewealth which they cannot control directly (Buggenhagen 2003: 197).

In his study of new forms of polyandry amongst female university students in Dakar, Biaya (2001: 79-81) identifies the various strategies they employ. There is the 'ménage à trois', where a girl combines her regular boyfriend with a thiof whose principal role is to provide finance and gifts in exchange for sexual favours, which the girl uses on herself, her boyfriend and her family. The 'ménage à quatre' is slightly more complicated in that, in addition to the regular boyfriend ('le chic') and the thiof as a wallet on legs ('le chèque'), there is also the intimate classmate at university who assists with class work and administrative headaches, and who once in a while is allowed to harvest sexual pleasures among others ('le choc'). This ' $3 \mathrm{Cs}$ ' phenomenon (chic, chèque, choc) is 
common on university campuses throughout francophone Africa and is said to be responsible for the culture of the ' $4 \mathrm{Vs}$ ' (villa, voiture, voyages, virement bancaire: 'villa', 'car', 'travel', 'bank transfers'), the material price thiofs must pay to be serviced by students who normally have their boyfriends with whom they would be contented, were it not for poverty (cf. Mbah and Soumaho 1996). In Tamatave, Madagascar, where a similar phenomenon has proliferated since the 1990s under the name jaombilo, young Malagasy men increasingly have to rely, albeit reluctantly and in shame, on young Malagasy female prostitutes 'who go out to work at night, and charge high prices' to mostly white clients, in order to provide for themselves and their unemployed and desperate boyfriends or husbands (Cole 2004a).

If disquettes are likened to spare tyres (les roues de secours), diriyankes are compared to the wheels of trucks ('les pneus de camions') and generally thought to be more difficult to manipulate. As a thirty-two-year-old husband and father of two told me, 'a man can always free himself from a disquette, but with the diriyanke, it is difficult to get detached once they are glued to you.' This might be because diriyankes invest a lot more in keeping their men. Indeed, some are said to do this so well that they could make even the most devoted religious authority forget the time for prayers ('Celle-là, elle peut faire oublier l'heure de la dévotion à n'importe quel vénéré religieux'). ${ }^{12}$ Whether with disquette or diriyanke, men are generally advised (by fellow men with experience or by women eager to eliminate rivals) to tread with care and, above all, not carelessly to eat food prepared for them by either. For if they really want to keep men, in everything they cook, there are likely to be charms specially packaged by marabouts - whom Senegalese visit, regardless of their religious affiliation, level of education or social status (cf. Biaya 2001 ) - to capture and cage love. Visits to marabouts are particularly popular among women (young women increasingly), with conflicts and jealousy over love and attention being two of the most common reasons for such visits (cf. Gemmeke 2002; Buggenhagen 2003: 116, 144). Early deaths among men with multiple partners may sometimes be attributed to 'bellies swollen with grisgris' administered by women who want to eliminate rivals and to ensure that their men are faithful and generous with money. According to Le Quotidien, Senegalese women are reportedly such experts at seduction that foreign women are said to guard their men jealously. The newspaper quotes a Cameroonian woman as saying: 'I am wary of Senegalese women, the Wolofs in particular. They have a frightening ability to seduce men. I am not at ease when my husband is in Senegal. He always comes back ruffled. ${ }^{13}$ Biaya (1999a, 1999b, 2001) and Ly (1999) have also written on the seductiveness of Senegalese women.

As indicated in the introduction, not every African gripped by consuming poverty has opted for the consumer bandwagon or done

\footnotetext{
12 <http:/www.lequotidien.sn/dossiers/article.CFM?article_id=148\&var_doss=27>

13 <http://www.lequotidien.sn/dossiers/article.CFM?article_id=148\&var_doss=27>
} 
so in the same way. This is just as true of Senegal, where, at the margins of all the consumerism, one notices a strengthening commitment to fundamental religious identities among Muslim and Christian communities alike, and to cultural values that privilege collective over personal success, and the need to invest in kin through remittances, marriage, investment at home even when one is permanently in the diaspora (cf. Buggenhagen 2003). Among Christians, the ('Born Again') Pentecostalists are a good example of the resolve to challenge contamination with moral uprightness in dress, sexuality and general comportment, and by being markedly negative or ambivalent towards ostentatious consumption. With Muslims, there is an equally long emergent countervailing tendency in the use of more globalized notions of Islamic dress on the part of women. Thus in Dakar, a significant number of young women can be seen in full hijab which does not have long historical antecedents in the country. However, while for the most part this dress may reflect the anxiety about moral dissolution and the strengthening of transnational Islamic ties, it too at times is deployed as an instrument to secure access to wealthy, strongly Muslim-identified commerçants, marabouts or politicians. Another strategy also noticeable in Dakar in recent years is the tendency for young women to go around in bands or cliques, adorned in such outrageous fashions as to make themselves beyond the reach of anyone, by being simultaneously attractive and repulsive beyond measure. ${ }^{14}$

\section{THE CONCEPTS OF THIOF AND YABOY}

Turning back to the language of consumerism, commoditized sex and sexified commodities, equally striking is the usage of thiof, the name of a most prized fish, ${ }^{15}$ in a variety of ways. In restaurants, those who order thiof are well regarded because this is an expensive fish that only the elite few can afford to eat regularly, if at all. Just like disquettes for the computer, which are available in various capacities (single, double and high density), the thiof comes as small (petit), medium (moyen) and $\mathrm{big} / \mathrm{super}$ (grand/super), and is priced accordingly. The human thiof is equally graduated, with the 'grand/super' occupying the highest status and greatest potential for generosity to disquettes, whom they sample in variety, debauchery and hedonism. It is with the 'grand/super' thiofs that disquettes stand the best chance of fulfilling their expectations of consumption and dreams of the ' $4 \mathrm{Vs}$ '.

Viviane N'Dour, a young, pretty, trendy female singer whose music is described as 'a mixture of the Senegalese mbalax and Afro-American $\mathrm{R} \& \mathrm{~B}$ rhythms', is very popular with her generation, sings regularly on love that often touches on relationships between disquettes and thiofs. ${ }^{16}$

\footnotetext{
${ }^{14} \mathrm{I}$ am particularly grateful to one of the anonymous reviewers for drawing my attention to this point.

${ }^{15}$ Epinephelus aeneus, Eng. 'white grouper'.

${ }^{16}$ See her album 'Entre Nous/Between Us'.
} 
In a song titled 'Bul Saalit', she features a rich thiof, 'director of the port', 'a most important man', 'grand monsieur' and 'superstar', who thought himself the smartest ('moi qui pensais que j'étais le plus rusé'), only to be outsmarted by Sally ('j'étais trompé, rejeté'), the disquette he thought loved him as much as he did her ('je t'avais placée à un niveau très élevé; je ne savais pas que tu me trompais'). ${ }^{17}$ This is a timely reminder by a female artist that thiofs remain manipulable regardless of their money and social status, and that ultimate power lies with disquettes. There is also a magazine named Thiof that describes itself as 'the monthly for the trendy' ('le mensuel des branchés') and focuses mostly on fashion and high society ('la jet set sénégalaise'). Richly illustrated with glossy photos, Thiof regularly features superstars (models, musicians, footballers, politicians, businessmen and women), with falling in and out of fortune as a central theme. ${ }^{18}$ These usages of the word, and others, seek to compare men to the prized fish. In general, but not exclusively, thiof in this sense refers to older, established, comfortable, rich (mostly married) men with a joie de vivre and appetite for younger women, preferably pretty university students and schoolgirls of modest social and financial backgrounds. ${ }^{19}$ Teachers and lecturers unable, because of low pay, to provide moyens sexuellement transmissibles ('sexually transmitted property') can always qualify as thiofs with moyennes sexuellement transmissibles ('sexually transmitted marks'). ${ }^{20}$ While within the school age bracket thiofs are generally handsome boys whom girls are fond of, among the older generation, thiofs may be physically handsome, but their looks are considered supplementary to their wallets, which are what disquettes fish for above all else. Their wallets are guarantee enough that thiofs shall pass from disquette to disquette - 'test-driving' ${ }^{21}$ them at will - and that it matters least whether thiofs are handsome or ugly, married or single, old or young, loving or lustful, decent or perverse.

This reality is well captured by the distinction made by some, including university girls, first between 'thiof de Dakar' (seen as more well-to-do) and 'thiof régional' (considered to be poorer and less sophisticated), and then between 'thiofs de Ngor' (seen as fresh, energetic and authentic) and 'thiofs de Dakar' (likened to the battered cars rapides, which are usually very old, used, reckless buses that pant and struggle along with expired youthfulness - 'thiofs presque périmés') ${ }^{22}$ Thus, if even the 'thiofs de Dakar' succeed in attracting disquettes, it is less

\footnotetext{
17 See her album 'Tere Nelav'.

${ }^{18}$ For example, each carrying the photo of a trendy and beautiful girl, the following were cover stories in recent issues: 'Celibattitude: la vie en solo' (no. 4, August/September 2003); 'Nos stars entre amour et desamour' (no. 5, October 2003); 'C'est la saison des rondeurs ... vive les fesses' (no.7, December 2003); 'Aida Ndong: belle forever!' (no. 8, January 2004).

${ }^{19}$ It should be noted that not all disquettes are necessarily of modest financial backgrounds, as some well-to-do parents are reputed to take very good care of their daughters, who are likely to seek thiofs for other than financial reasons.

${ }^{20}$ See p. 320 , fn. 47.

${ }^{21}$ I am grateful to Rudu Gaidzanwa for describing the objectification of women in these terms.

${ }^{22}$ Within the city of Dakar.
} 
because of their natural attributes than the size of their wallets. Talking to adults, one gets the impression that thiofs used to be educated city men with salaried jobs, the sassoumen of yesteryear. Nowadays, it is not the case; the most eligible thiofs in Dakar are not necessarily well educated, given the limitations of education as a magic wand, and some indeed hail from rural parts of the country. These days, apart from the imported breed, thiofs are either traders from the informal sector, musicians who have struck it rich, footballers playing for lucrative clubs, or just Senegalese migrants living and working abroad, since emigrating to deeper and richer waters seems even better than landing a thiof locally.

The class of 'grand/super' thiof comprises the cream of the local elite-foreigners who are mostly Europeans or Africans in the diplomatic service, the Lebanese who dominate the world of business in Dakar and les venants (diasporic Senegalese who visit home from time to time or who make friends and family smile through electronic money transfers via Western Union [cf. Buggenhagen 2003]). ${ }^{23}$ What most distinguishes the grand/super thiofs are the latest, flashy cars they ride, state-of-the-art mobile phones, sumptuous villas in upmarket parts of town and an appetite to explore restaurants, hotels, beaches and resting-places (circuits) with disquettes - 'pourvu que l'on se cache'. The medium and small thiofs comprise a more mixed bunch of civil servants, businessmen, university lecturers, students and others of diverse backgrounds and modest fortunes. In all three categories, it is possible for a thiof to really distinguish himself through extra acts of availability and generosity - in which case he might be referred to as unequalled (un thiof hors pairs or un thiof deluxe). In some situations, a thiof might be completely swept off his feet by a disquette who manipulates him at will, like someone parcelled up and absent-minded (un thiof emballé), completely disabled (un thiof en pièces détachées), totally shaved (un thiof complètement plumé ou écaillé or un thiof ngot) ${ }^{24}$ or truly outclassed (un thiof déclassé). In such situations the disquette pulls the strings and is often said to have the thiof at her beck and call. But to stay on top, the disquette constantly has to make concessions to the sexual whims and caprices of her thiof, who may or may not be inspired by the angel of death. In the case of the grand/super thiofs, such whims and caprices could be quite daunting, given their cosmopolitan identities and fantasies, and given their culture of 'value for money'.

Among the young thiofs are 'des fils à $p a p a$ ' who are often very rich by proxy, drive fancy cars and are chased after by disquettes. Handsome young thiofs who may not have the finances to pull their weight with disquettes in Dakar might opt to service the appetites of rich diriyankes

\footnotetext{
23 As a low-income country with very limited economic opportunities back home, the Senegalese state, religious communities, families and relations not only encourage migration (especially to the USA, France, Italy, South Africa and other zones of 'milk and honey'), they depend heavily on remittances from diasporic Senegalese (Buggenhagen 2003: 21-31). The state has recently created a ministry in charge of Senegalese in the diaspora.

24 'Thiof ngot' could also mean 'thiof hors pair' ('super super thiof').
} 
in exchange for financial support which some of them use in turn to entertain their fantasies with the choicest disquettes. In this way, they are just as animated by the reality of ' $3 \mathrm{Cs}^{\prime}$ ' and ' $4 \mathrm{Vs}$ ' as are the disquettes who chase.after the grand/super thiofs. But not all young thiofs in liaisons with diriyankes are there just for the money, for, as the saying goes in Dakar, 'it is in old pots that the tastiest dishes are made." ${ }^{25}$ And above all, 'when a Senegalese lady goes hunting, she never comes back with an empty bag,, 26 for no reason other than the fact that she knows her way with men. 'While it is said that men are boroom ker, or the heads of households, women are boroom neeg, head of the bedroom, which is to say that they influence men's decision making in matters private and public in the intimacy of their bedrooms' (Buggenhagen 2003: 142). Proof of this can be judged by how much women invest in a variety of exotic perfumery, scents and practices to enrich their 'cult of eroticism', ranging from the incense (thiouraye) to 'the pearl belts soaked in a cocktail of diverse perfumes'. Ly (1999: 46-7) refers in particular to 'nemali, a name given to incense which, in Wolof means "finish" (the man) because of the aroma it emits'. There is also the gongo, which they use in the form of small balls wrapped in thin cotton, preferably small gauze squares, which makes it possible to exhale the scent' and which women place under the armpits or tie to a bra-strap. Other accessories include gowe, diguidieu, naq, a whitish powder called glace, and a special toothpick preferred by mothers and engaged women keen to give impressions of virginity. The béthio ("petits pagnes'or 'mini wrapper'), considered a specialty of Senegalese women, is worn under the nightgown to 'prepare the night or the bed', and given various sexy names inspired by sexy music and fantasies. These products are said 'to bewitch and turn men's heads', making them lose reason, stay still and stay in love, regardless of whether they are dressed in ties or in boubous ('she wants to share unforgettable moments with her man, so that he will always come back to her'). As one lady put it in a newspaper article, 'these products are like the Maggi. They make the meal taste better. ${ }^{27}$ These traditional perfumes and scents are more likely to be worn by diriyankes than by disquettes who are inclined towards modern perfumes, in the Western consumerist sense - perfumes often advertised in Thiof magazine and on satellite consumer television such as Canal Horizon and readily available in duty-free shops and supermarkets and bought as gifts for disquettes by the top class men who keep them. Through their perfumery and eroticism women make their men 'more willing to consider their requests for numerous things' (Buggenhagen 2003: 142).

While the grand/super thiof is most secure with disquettes, given his impressive purchasing power, the petit thiof is most at risk of being overtaken by young upstarts often referred to as yaboys. The latter is a

\footnotetext{
25 'Les vieilles marmites font des meilleurs plats.'

26 'Quand la Sénégalaise part à la chasse, elle ne revient jamais bredouille.'

$27<$ http://www.lequotidien.sn/dossiers/article.CFM?article_id=148\&var_doss $=27>$.
} 
rather bony, ordinary, irritating sort of fish that is difficult to swallow. Accordingly, the men who bear this designation have little but trouble to offer the high-density disquette in quest of consumer excellence. The abundance of bones means the yaboy could stick in the throat of a disquette, become a health hazard in an obvious way, and pose more of a liability than an asset. Rich people minimize contact with the yaboy, claiming allergies as excuses so they can avoid it. Only the very poor or the desperate shop for the yaboy, compelled to make do with the bones and, at the end of the day, find it a very tasty fish. Without its bones, the yaboy could well be as prized as the thiof. Disquettes, who frequent yaboys soon become unreadable, even in the best of drives. According to a beautiful twenty-year-old university girl, yaboys will pierce you all over ('les yaboys te piquent partout') and are a great inconvenience. And by way of relativism again - the exception that proves the rule - I was occasionally told by young girls and women that being thiof or yaboy depends on how a man is perceived and related to by a woman. Hence a mbarane can be a yaboy or a thiof depending on the type of relationship he enjoys with a chosen woman, since it is quite possible to be considered a thiof by some and a yaboy by others. Feelings, needs and social position of women not being the same, the standards for a thiof or a yaboy are bound to vary from woman to woman.

Subjectively however, if a disquette frequents a yaboy, it is often for want of an alternative in the form of a thiof or because the disquette has decided that the thiof will bring material comfort while the yaboy provides emotional, even if taxing, satisfaction (like in the ' $3 \mathrm{Cs}$ ' and ' $4 \mathrm{Vs}$ ' discussed above). With the yaboy however, a disquette must be on her guard in order not to be depleted, distorted or physically damaged and betrayed. Given that thiofs are not wholly trusting, they often set fidelity traps for their disquettes and some do not hesitate to dump a disquette who is caught using their resources on yaboys. Hence secrecy ('pourou que l'on se cache') is just as important to disquettes as it is to others in Senegal (cf. de Jong 2004). Since even a yaboy could benefit from upward mobility, the more dynamic amongst them are likely to rub shoulders with the 'petit' thiofs, who feel constantly threatened by their ambitions and hard work. While disquettes might find emotional satisfaction in yaboys, they are likely to pursue thiofs for financial and material fulfilment. Yaboys might love and be loved, but at the end of the day, 'one cannot survive on love alone'. ${ }^{28}$ Love for the sake of love is likely to stick in the throat of even the most tolerant of disquettes, or those who depend on them, with fatal consequences.

Despite the nuances, some men who see women essentially as commodities would still maintain, firstly, that a disquette's greatest ambition is to be 'thiofed' (rendering her une disquette thiofee). Secondly, that the disquette hopes to be able to say ' $j$ 'ai un grand/super thiof deluxe', which is the ultimate proof of her abilities and luck in attaining quality 
fish. For, with the grand/super thiofs, disquettes can be initiated into swimming in the material abundance beamed at them daily by the industries of desire and consumerism through global entertainment television providers like Canal Horizon. It may happen that a disquette loses her thiof to another disquette with more luring baits. In this predicament she is said to be 'de-thiofed' (thus becoming une disquette déthiofée) and should normally be worried and uncertain. It is largely believed they will pursue every possible option to regain attachment, so no avenue is beyond contemplation, including regular visits to marabouts for fortification with inducement charms, amulets, concoctions and lotions. To be dethiof ed is every disquette's worst nightmare, regardless of how the thiof was caught in the first place. Unlike a thiof who expects takku deun (an appeasement fee) from the thiof to whom he loses a disquette, the latter do not enjoy a similar privilege. With some good fortune and facilitation by marabouts, a dethiofed disquette might get 're-thiofed' (une disquette rethiofée). While thiofs need money to keep their disquettes, disquettes invest a lot of energy, vigilance and assistance from marabouts to watch over their precious but capricious catch. A thiof, whether as a wallet, as a meal or as both, is the object of intense competition for attention by disquettes of various capacities and motivations. Disquettes invest remarkably in making themselves beautiful and desirable for this purpose. As Abdoulaye Ly (1999) and Tshikala Biaya (1999a, 1999b, 2001) tell us, investing in the culture of beauty and elegance takes forms that range from lavish hairdos to exotic perfumery and scents through dressing and consumerism.

These metaphors are significant, well chosen and especially profound for the way they encode the historicity of local linguistic repertoires. My conversations, sometimes provocative but often jovial and convivial, with both Senegalese and foreigners of all ages and social positions have revealed a fascinating richness in the way these notions are employed today in a Dakar gripped by the alluring images of the global industries of materialism, desire and sterile consumption. While the origins and meanings of these notions may have been specific, concepts - like identities - are dynamic realities open to new meanings with new encounters. That is why to define rigidly is to exclude social action that harbours the potential to redefine. Today, with the proliferation of computers, cybercafés and HIV/AIDS (even if Senegal is said to have one of the lowest infection rates on the continent), and with increasing exposure of Senegalese to the lexicon of hardware and software, viruses and anti-viruses, infection and disinfection, the original notions of disquette, diriyanke, thiof and yaboy have taken on additional meanings. Thus, while most informants were familiar with the latest meanings of these concepts, only some stressed the original denotations and connotations.

\section{ASSOCIATIONS WITH COMPUTERS AND VIRUSES}

This section stresses the association with computers and viruses that most likely comes to mind once the term disquette is mentioned 
nowadays. 'Une disquette', for example, has several resonances. First, the term suggests a modern container that is easy to carry and access, flexible, slim and light, with a phenomenal capacity despite its modesty in size. The joy of disquettes is more than just the capacity to store volumes. They can also be formatted and reformatted, customized and re-customized. In short, their strength lies in their capacity for self-regeneration and renewal. In this way, disquettes are never fully appropriated, as there is always the possibility of becoming virginal once more, even after they are filled up and personalized. Therefore, whether disquettes become marked, lose their virginity or preserve their autonomy by remaining socially blank, the circumstances in which they are enmeshed remain more situational than permanent. In principle, the situation can always be reconfigured.

A human disquette is there to be - or at least give the impression of being - appropriated and domesticated in the same way that a blank computer floppy disk (disquette) is formatted and labelled by different users according to the specifications of their floppy and hard drives. Human disquettes, like computer disquettes, are varied in sizes and capacities, although the slim 3.5 double or high-density disquettes, like Barbie dolls, are preferred because of their carrying capacity, portability and manoeuvrability. In conversations about disquettes, one could imagine une disquette vierge ('blank disk') to be formatted $\grave{a}$ goût précis ('according to specifications'), une disquette à double face/haute densite ('a double-sided/high-density disk'), with a capacity to carry far more data than its deceptive slimness would suggest, and une disquette testée et certifiée 'tested and certified' as being okay and virus-free. The flexibility of the disquette also means that data can come and go effortlessly, either by the same user or by new users. In other words, disquettes can be formatted and re-formatted, filled up, erased and refilled, without much 'personal' discomfort, if well taken care of.

In reality however, for the women to whom the term is given, the flexibility of disquettes entails that their virginity or 'innocence' cannot be taken for granted, especially when a family is interested in having a disquette for a wife. As people invest a great deal in allegory and euphemism, to 'put in doubt the morality, integrity and chastity of the newly-wed' would entail, for example, confronting her with critical remarks such as, 'we cannot be fooled: we are well informed that you are the tree on which generations of men have learnt to climb.... Sometimes she is likened to a well that has dried up, implying 'a sex that has lost its lubrication in nymphomania'. These days, such doubts mostly target urban disquettes, who are increasingly affordable because of falling prices and rising poverty. Since a blank/virgin disquette in the absolute sense is rare, some disquettes keep up appearances with 'fake' virginity to save face. In rare cases in which virginity is authenticated, 'chastity will be recompensed' by a week of extravagant celebrations referred to as ndampaye (Ly 1999: 46-7). It must be stated however that, increasingly for disquettes, losing their virginity is not their biggest problem, since nowadays many young women get married without that cherished attribute. The problem for those with marriage in mind is 
losing their virginity to somebody who does not end up being their spouse. After encountering such problems, many young women go for expatriates or white men who are believed to be less fussy about virginity. A reaction that might further alienate the women in question is the judgemental eye of the Senegalese men who, as self-appointed custodians of tradition, are inclined to believe that no self-respecting Senegalese woman should marry a white man, a nyak (inferior African) or an expatriate, unless of course, the woman in question is of an inferior caste (cf. Dilley 2004: 201-7). 'Whites marry those whom we have rejected,' affirmed a taxi driver, whose caste unfortunately I never sought to know.

Thiofs who are financially sound may not be sexually satisfactory. In certain cases, disquettes seeking more than pecuniary pleasure are forced to resort to aphrodisiacs 'to delay their partners' ejaculation'. Writing about eroticism among the Lawbe, Abdoulaye Ly refers to safal, 'a round, white pastille' believed 'to complement' virility when 'introduced in the vagina before love-making and melt during the sexual act' (Ly 1999: 46). Aphrodisiac foods include small lump sugar, pobare, ginger, pepper and cassava. The use of aphrodisiacs is common among women - married or unmarried, young or old, Lawbe or not (cf. Biaya 2001: 78). ${ }^{29}$ As a female colleague at work put it, 'Competition is not only before marriage. After getting married, you have to prevent your husband from looking for another wife by satisfying all his needs and all his fantasies. In a country where polygamy is common, competition is fierce, and women in polygamous marriages are always looking for ways to outdo their rivals.' Notwithstanding these investments in pleasure, the penis is often represented as an instrument of terror and, during tam-tam dance sessions, women may, with the help of the Lawbe sculptor, 'terrorize their age group with a wooden penis which they attach with the help of a thin cord tied around the waist' (Ly 1999: 46). Tam-tam dances are frequent in Dakar and provide girls - and, in some cases, homosexuals referred to as gordjiguène ('man-woman') - with the opportunity to indulge in some of the most suggestive, flexible, nimble and vigorous movements of the legs and loins, assisted by their mini wrappers topped by a pile of bine-bine or dial-diali pearl belts, worn around the waist, which, as noted above, are part of the erotic paraphernalia of Senegalese women. ${ }^{30}$

The flexibility and hospitality of disquettes also come with other risks, as they are extra vulnerable to zones of turbulence and mortal danger. Apart from the occasional excess of zeal and lack of selfmastery that have sometimes pushed hard drives to overindulge by writing themselves indelibly into the future of reluctant disquettes, there are more life-threatening risks. It could happen that by sheer

\footnotetext{
$29<\mathrm{http}: / /$ www.lequotidien.sn/dossiers/article.CFM?article_id=1488var_doss=27>.

${ }^{30}$ For details of a Tam-tam dance at HLM in Dakar, see " "Sabar" or strip-tease, the Senegalese style', in Air Senegal International, January 2004, by Seynabou Diallo, PANA correspondent.
} 
fact of sampling different floppy and hard drives, a disquette picks up a virus, a damaged surface or more, especially as computer users operate at different levels of sophistication and do not always have the consciousness or assets required to conduct regular maintenance and update their immunities. This is particularly dangerous for both the disquette and the hard drives it frequents, especially given the fact that a disquette, be it potent or passive, depends on the hard drives for protective software against viruses. A poisoned hard drive with weakened defences is therefore a dangerous highway for the disquettes that frequent it. Unsuspectingly, a disquette vierge ('virginal') formatted and consumed by infected disk drives, soon becomes une disquette $\dot{a}$ virus, given its vulnerability and relative passivity in interactions with disk drives. In addition, a disquette's innocence of appearance makes it an ambivalent container capable of recycling pleasure and pain in equal measure. Since its health is dependent on the soundness of the hard and floppy drives that consume and manipulate its contents, the disquette can only be safe if the drives are protected by the latest anti-virus software or if drives keep their appetite for disquettes in check. But disquettes are far from being entirely at the mercy of hard drives, since they can deliberately limit access to themselves by making use of protective features such as tabs, customized formatting and passwords.

Paradoxically, although generous drives are dangerous drives, human disquettes often depend precisely on the generosity of drives for social visibility and material survival, by targeting particularly ambiguous hard drives, for example, known in Botswana as MBA (Married But Available). Their pursuance of what among university students in Dakar and Libreville is known as the '4Vs' and the '3Cs' (cf. Biaya 2001; Mbah and Soumaho 1996), is not divorced from the risks and shocks of reckless exposure, when the hard drive passes from giving pleasure to sowing terror. In other words, a disquette comes to life meaningfully through unmeasured interaction with multimedia drives, but given the uncertain realities of most drives, who can state the fate of their teranga with certitude? Disquettes are active social beings par excellence! Yet in some ways, they are passive victims of structural inequalities as well! Could the problem therefore be with drives that are overly generous as containers, drives as superhighways? Drives as filling stations that serve and service indiscriminately? Drives as appetite gone wild? Drives as dangerous virility and potency? Drives as terror?

The answer may well be in thiofs who, like butterflies, prefer to sample several dishes rather than the monotony of 'eating only eggs day in and day out', to quote a Zambian husband (Ferguson 1999: 185). As the saying goes, 'rares sont ceux qui traversent le même fleuve deux fois. ${ }^{31}$ Competing brand names and models entail competitive consumption, as any attempt at permanent appropriation counters the

31 'Men seldom cross the same river twice'. 
logic of consumer sovereignty. The Cameroonian satirical comedian Tchop Tchop captures this eloquently in his sketch titled 'Mini Minor', which, although intended to discourage promiscuity and check the spread of venereal diseases and HIV/AIDS, is unfortunately extremely misogynist in tone. A married man, tired of being served 'potatoes' several times a night, ventures out with disquettes in mind, only to be rewarded with pleasure diminished by pain. He uses the imagery of a filling station attendant working at the 'World Petrol Station', servicing vehicles of all shapes, sizes and ages, whose confidence in an innocent looking 'Mini Minor' (disquette) endangers his petrol pump and lands him in trouble. Here is an excerpt from the ordeal:

Of all these cars, I chose the smallest, the most attractive, a Mini Minor. And she had just arrived in the filling station. The Mini Minor, even though a little car, its back is uplifted, and it is curved, with a round bottom and a protruding front. When you look at the head of the car, it has small eyes like this, but if you stand back a little, it is swollen, rounded, a cute little car, a car like it just came out of the manufacturers. I could not imagine that people could have cars like that. You could not even imagine a defect in the gas tank of such a car. I said no, it is in this car that I will serve my gas today. Instead of stopping like the other cars, it crosses. Here I am following it. I make a sign. I say, waro, waro, waro. The car stops. I say, do you need gas? $H e ́$ hé. A deal is reached.

Now, I have to fill the tank. We backed up behind Ste Bernadette. I found a good fuel tank. We stopped at a warehouse. I took my petrol pump out. I thought the size of it would worry this small gas tank, but the Mini Minor widely opened its small reservoir, as if it had been visited by another gas station attendant. I sunk my petrol pump deep without difficulty. It went all the way to the bottom of the gas tank. That is how the gas was freed and reached its objective. I get my petrol pump out and put it away and go home. Twenty-four hours only after that, I try my petrol pump. It was now leaking red gas oil. I ask myself, how? I run away from big trucks for fear of defect, now my petrol pump breaks down in a Mini Minor? What is this? After some twenty-four hours, the pump leaked only concentrated milk... ${ }^{32}$

Newspapers regularly carry stories of disquettes preying on thiofs like praying mantises. ${ }^{33}$ Not only do such disquettes fish in troubled waters, they trouble the waters with their fishy fishing. The press has carried reports of girls who would lure men to hotel rooms or to their homes with promises of having a good time, only to drug them and strip them of their money, mobile phones and other valuables. Known in the press as 'la drague numérique', the strategy is for the disquettes to procure the mobile phone numbers of their potential victim and then to send an SMS text message inviting the victim to 'meet them at a hotel or rest house for a sex party'. ${ }^{34}$ Distracted by alcohol and the prospects of love

\footnotetext{
${ }^{32}$ Excerpt from Tchop Tchop's 'Mini Minor', a sketch on the dangers of promiscuity.

${ }^{33}$ Of significance is not so much whether the stories are credible or not, but rather the fact that there is room and readership for the papers that carry them.

34 'Rendez-vous dans un hôtel ou une maison de passe en vue d'une partie de jambes en l'air.'
} 
with a pretty disquette, the thiof falls prey first to a doctored drink and then to the loss of money and valuables.

In one particular case in September 2003, the police were reported to have put an end to the crookery of two high school girls, Marie Rose Seck and Soukeyna Bâ, who defrauded mostly VIPs by sending them love text messages, arranging to meet at a given hotel, then drugging them and making off with their valuables. In three months, the girls, described as 'deux délinquantes numériques' and said to have failed their $b a c,{ }^{35}$ reportedly amassed valuables and money worth 10 million CFA francs. Writing in Le Témoin, ${ }^{36}$ Pape Ndiaye described the girls as armed with 'a radiant beauty they use as bait'. ${ }^{37}$ In general, the SMS text messages sent to clients were variations of the following, which Marie Rose Seck purportedly sent an MP: 'Honourable member of parliament, do you remember me? Ever since I have not stopped thinking of you. Presently, I am without underwear, almost naked. Really, tonight, I would like to experience a parliamentary penetration, whenever you like, wherever you like. ${ }^{38}$ For others, it's simply: 'Honey, I want you today, I am naked and without a partner. ., ${ }^{39}$ In the case of the MP, he fell for it and was drugged, only to wake up in the morning to realize the disappearance of his briefcase containing the salaries of his employees estimated at 6 million CFA francs, and of a Nokia mobile phone estimated to be worth 150,000 CFA francs, a gold bracelet, a watch and fuel coupons totalling 100 litres. ${ }^{40}$ For the girls, working as a pair was said to be very convenient, for 'if the one succeeds in getting a partner and can't satisfy him because of her period, for example, the other takes over so the client can have satisfaction'. ${ }^{1}$ The two are said to have enjoyed attending banquets, official ceremonies, marriages, meetings and parties with the sole aim of targeting personalities and their mobile phone numbers. Part of their success came from playing around with various identities, making up fake names and passing themselves off as university students and marketing agents.

While some disquettes are capable and confident of fishing for the grand/super thiofs, others settle for a more modest game in the person of the petit thiof or even the yaboy, as the following case, reported by Alassane Hanne in Le Populaire, ${ }^{42}$ demonstrates. A certain Fatou Samb

${ }^{35}$ Le baccalauréat, final exam at secondary school.

${ }^{36}$ Le Témoin, 17 au lundi 22 septembre 2003, $\mathrm{N}^{\circ} 680$.

37 'Une beauté radieuse et éclatante qui leur sert d'appât.'

38 'Monsieur le député! Tu te souviens de moi? Depuis lors, je ne cesse de penser à toi... Actuellement, je suis sans slip. . presque toute nue. . . Vraiment, je veux goûter ce soir une pénétration parlementaire... Oti tu veux, quand tu veux...'

39 'Mon chéri. . j'ai envie de toi aujourd'hui... je suis toute nue et sans partenaire. ..'

40 ' $L a$ disparition de son cartable contenant la masse salariale de son entreprise estimée à 6 millions $F c f a$, de même qu'un téléphone cellulaire de marque 'Nokia' d'une valeur de 150000 Fcfa, un bracelet en or, une montre et des bons de carburant pour 100 litres.'

41 'Si l'une réussit à décrocher un partenaire et se trouve dans l'impossibilité de le satisfaire à cause de ses règles menstruelles, par exemple, l'autre se substitue à elle pour contenter le client.'

42 Le Populaire, lundi 29 Septembre 2003, N 1162. 
convinced Assane Ndiaye, a trader ('un marchand') to follow her home under the pretext that she wanted to purchase his mobile phone. Once at her home, she is said to have drugged him, had sex with him and then stolen his mobile phone and some money. The strategy is similar although the actors are modest in status and the sum less significant. On Wednesday 24 September 2003 at 2 p.m., contact began at an inner-city eating-place (gargote) called Kër Fatou Guèye, situated at the Thiaroye railway station, where the famished petty trader was having a meal of rice. It was while he was eating that Fatou Samb, aged 25, quietly came and sat by him. After teasing him about his manner of eating, she pointed at his mobile phone and said: 'You have a beautiful mobile. Would you sell it to me?'43 Assane Ndiaye replied: 'If you have money on you, I can sell it right away. ${ }^{44}$ Not having money on her, Fatou Samb succeeded all the same in convincing the young trader to accompany her to her place situated nearby. According to Assane Ndiaye, once home, 'she put me in bed before serving tea, I fell asleep right away. Fatou Samb woke me up in the middle of the night by slapping me. I then started to come to my senses. She undressed me and aroused me by sucking my p... After that, she took a condom from her closet and we had sex. When I had ... she again served me a red drink and I pass out again until about 10 a.m. ${ }^{45}$ When he woke up the following day, Assane Ndiaye remarked that his mobile phone and the sum of 27,250 CFA francs had vanished from his pocket. Then it dawned on him: 'She had drugged me in order to make away with my valuables'. It is worth noting that the disquette, while doctoring drinks and luring an unsuspecting libidinous individual into her snare, still had the decency or self-serving sense of preservation to offer protective devices.

With such experiences in mind, some men have likened disquettes to millipedes suggesting that, in either case, you can never be sure which of its thousand legs will be used: disquettes are seen as keener to render thiofs wretched than to enhance and make thiofs comfortable. The disquettes might well be justifiable in what they do, given the patriarchal context in which women seek and access social opportunities. As Phil Okeke (1998: 17) notes of Nigeria, where 'bottom power' is common currency, a good number of women are compelled to use 'their relationship with men to improve their life chances' in a system with little visibility for them, and a social context where their mobility is in many ways tied to their relationship with men. In Tanzania as well, 'the notion that female sexuality can be bartered for economic gain gives women the right to

43 'Tu as un beau portable. Tu veux me le vendre?'

44 'Si tu as des liquidités sur toi, je peux te le vendre tout de suite.'

45 'Elle $m$ 'a installé dans sa chambre, sur sont lit, avant de me servir du thé, je me suis endormi aussitôt. Fatou Samb $m$ 'a réveillé en pleine nuit en me donnant des coups de gifle. En ce moment, $j$ 'ai commencé à reprendre connaissance. Elle $m$ 'a déshabillè et $m$ 'a excité en suçant mon p.... Après cela, elle a sorti de son armoire un préservatif et nous avons eu des rapports sexuels. Quand j'ai..., elle $m$ 'a encore servi une boisson de couleur rouge et je me suis endormi à nouveau jusqu'au lendemain vers 10 heures.' 
negotiate with men to secure their own economic and social security', thereby compelling men to 'earn' female sexuality and reproductive power (Haram 2004: 227). It could be argued that, so long as states, laws and cultures continue to be paternalistic, nurturing and glorifying men and boys at the expense of women and girls, and so long as men continue to treat women as objects for their sexual gratification, they must realize that women will always view them as a fat wallet on legs, a meal ticket or a stepping stone to greener pastures which may or may not include access to grander thiofs. But the very fact of having to depend on disabling disk drives to seek autonomy reinforces the subordination that denies disquettes their status as social actors in their own right and on their own terms. Worse still, the pervasiveness of physical and social hazards (i.e. fatal infections, unwanted pregnancies, the poisons of tensions and conflicts with and between thiofs, stigma, etc.) associated with such opportunism cancels out any equalizing effects. At the end of the day, the only solution to their predicament as endangered disquettes comes not from seeking to beat thiofs at their own game, but by radically subverting the phallocratic and consumerist order that makes of thiofs champions of disorder. How to do this in a context of chronic poverty and a sharpened appetite for consumerism remains the question. But better a legitimate question without an answer than a diversion.

\section{CONCLUSION}

In Africa, consumerism gone awry is not confined to Dakar (cf. Comaroff and Comaroff 1999; Nyamnjoh and Page 2002; Cole 2004a, $2004 \mathrm{~b}$ ), as everywhere the global tele-evangelism of consumption is converting Africans into various degrees of consumerism and seeking to mould especially youth into consumer zombies (cf. Nyamnjoh 2002). Neither is the use of metaphors in the above sense limited to this specific scenario. Contact and interaction have exported the creative notion of disquette to neighbouring Bamako, where big men are said to adore 'les jeunes filles bien roulées' whom they 'consume without moderation', to the point of 'indigestion' ${ }^{46}$ In Abidjan, on the other hand, the metaphor of choice and equivalence of the disquette is cellulaire or portable. Just as the flexibility and movableness of the mobile phone are contrasted with the rigidity or fixity of the landline phone, the girlfriend is seen as more accessible and less orthodox than the wife. The slimness and youthfulness of the girlfriend, like those of the mobile phone, are perceived to be more exciting by men in love with total control of youth and women. Young and trendy, brandishing their mobile phones, school and university girls are most popular with MBA ('Married But Available') in Gaborone, who are so determined to control them that they regularly buy their girlfriends pre-paid units

${ }^{46}<$ http://www.essor.gov.ml/sem/cgi-bin/view_article.pl?id=6008>. 
for their mobile phones so as to stay in touch. The ease with which mobile phones change owners in Abidjan, Gaborone and elsewhere in Africa is comparable to thiofs gaining and losing disquettes in Dakar. It would appear - to paraphrase the EU Transport Commissioner Neil Kinnock (courtesy of Sky News) - that the mobile phone is one of those rare items for which men are ready to compete on who has got the smallest.

In Harare, 'small houses' is the term for high-maintenance mistresses who are pampered with jewellery, houses in expensive northern suburbs, all-expenses-paid holidays, new Mercedes, sexy mobile phones (the smaller the better), cash, and full makeovers (i.e. pedicure, manicure and expensive hair pieces) at hair salons. In addition to mistresses, men have teen girlfriends of school-going age that they call ' 16 valves'. In Nairobi, ndogo ndogos (Swahili for 'small small') is used to describe disquettes, who are sometimes labelled after the latest car number plates to denote their currency, trendiness and desirability. In a context of rapid urbanization and compounding misery, Kenyan thiofs consider it 'national service' or an act of philanthropy 'to assist' ndogo ndogos in high school and university in exchange for sexual favours. Girls are flattered with false promises of BMW ('Be My Wife') by older men to whom no girl seems too small for them 'to cover the face and hammer the base'.

In urban Cameroon, there is a rich collection of metaphors on the same theme, ranging from the famous 'deuxième bureau' where working men spend most of their time between home and office, to mboma ('boa constrictor') who crush and swallow their victims alive, thanks to their purchasing power. Stories linking prominent men with bizarre ritual sex are the order of the day. In 1994, following a double slash in civil servants' salaries and a 50 per cent devaluation of the CFA franc, rumours of mystical occurrences connected with sex and sexuality were commonplace. In Limbe, rumours suggested that Igbo businessmen from Nigeria were making local men's sexual organs shrink or disappear, simply by shaking hands with them. Limbe women were rumoured food for Nigerian business tycoons' penises. Around the same time, it was alleged that two girls from the University of Yaounde had fallen victim to a foreign tycoon. Stories claimed the girls dated the man and later returned to his posh residence in the Bastos area. Rather than sleeping with the girls, the foreigner chose one and allegedly transformed himself into a boa constrictor and began to swallow her. When the other girl realized what was happening, she hastily departed and alerted the police. The police investigation supposedly revealed that this was common practice for this man. On 15 February 1999, a girl known simply as 'cousine Elise' phoned the Yaounde FM $94 A$ Coeur Ouvert presenter Joly Nnib Ngom to accuse 'a well placed personality of the Republic' whom she had dated for six to seven months of having given her a boa constrictor in the form of an expensive gold necklace. Rumour immediately associated Gervais Mendo $\mathrm{Ze}$ - general manager of Cameroon Radio Television, whose mystical totem is a boa constrictor that sucks the blood of young virgins 
whom he entices with money and expensive gifts of necklaces - with the girl, and matters worsened when Mendo Ze suspended the programme's presenter (Nyamnjoh 2001: 33-4).

In the Igbo-speaking part of Nigeria, thiofs are regarded as omatas ('rich traders'), while the 'lucky' ladies that depend on them for their upkeep are regarded as 'omata babes'. Omatas are usually illiterate traders, mainly from Onitsha, who are ready to spend 'stupid' money on 'gullible' ladies. Among undergraduates in Nigerian universities, the thiof equivalents are aristos (young bankers, oil workers or rich business men who come for female students every Friday night), while the yaboys who cannot compete with the aristos are regarded as 'bushmeat' (in most cases poor and hungry looking). The beautiful girls, not necessarily slim, who are able to attract the aristos are regarded as ajebutter (people that have a soft life, eat butter and do little work to make ends meet), as opposed to ajepako (those who eat wood, toil and strain to make ends meet). In Lagos and among African student circles in the UK, some men are said to go for 'laptops' that are portable and easier to manipulate than bulkier, heavier 'desktops', which are devoid of the excitement of flexibility and mobility. The 'flashdisk', the latest sensation to catch the fancy of the super thiof, poses a challenge to the conventional disquettes, who are reluctant to imagine themselves yet as the diriyankes of tomorrow. Similar metaphors abound throughout the continent and among Africans in the diaspora.

The metaphors may be pointers to ongoing processes that could, if researched, inform theory and policy on and around uncertainties in contemporary African lives at home and in the diaspora. In a continent pregnant with poverty, where the tendency is to consider 'single', 'free', 'unattached' or 'husbandless' women as 'prostitutes' (cf. Haram 2004), and to reduce sex and sexuality to the whims and caprices of the penis - 'no penis, no sex' (cf. Arnfred 2004a: 18-25) - phallocracy, or the dictatorship of the penis, is the order of the day, stretching from the helm of state down to the ghettoes and villages (cf. Toulabor 1981; Mbembe 1992, 2001; Diamani 1995; Nlandu-Tsasa 1997; Biaya 2001), denying women the recognition and representation they seek for their complex identities and sexualities (cf. Arnfred 2004b). No place seems too remote, too sacred or too civilized to be penetrated and humbled by symbols of male power, and 'women [must not] forget that men are the masters', as a study of Kisii District in Kenya shows (cf. Silberschmidt 1999: 153-69). In many a country official rhetoric associated with presidential powers is easily corrupted with insinuations of prowess. Thus in Zaire, where President Mobutu, in his quest for omnipotence spared no one, 'Mobutu Kuku Ngbendu Wa Za Banga', which officially meant 'Mobutu the great warrior who triumphs over all obstacles', was corrupted to read 'the cock that spared no hen'. Popular rumour dramatized the president's abilities with women, especially the wives of ministers and close collaborators, who in turn inflicted revenge on the wives of juniors and on university and high school girls. Ultimately, the slogan 'Tata bo moko! Mama bo moko! Mokonzi bo moko! Ekolo bo moko!' ('One father! One mother! One chief! One country!') was 
corrupted to read 'Mobali bo moko' ('One husband'), not in celebration of monogamy but in recognition of presidential promiscuity as the only cock in a republic of hens (Diamani 1995: 152). Toulabor (1981) offers similar examples of word play and presidential power in Togo under Eyadema.

Schools (cf. Menthong 2000) and universities (cf. Biaya 2001; Moutome Ekambi 2003) are part of the postcolonial phallocracy, where, to quote Achille Mbembe, 'pride in possessing an active penis has to be dramatized' by male academics seeking 'the unconditional subordination of women to the principle of male pleasure'. In some cases, female students are made to understand that the 'heat of [their] thighs' or the 'miraculous properties of their cowl' could deliver certificates faster than could their intellect (Mbembe 1992: 9-24; 2001: 127). Hence the celebration of violence against female students and the prevalence of sexually transmitted marks (cf. Moutome Ekambi 2003: 45-53) ${ }^{47}$ with or without mitigation from fear of HIV/AIDS. Despite countless safe-sex campaigns, many remain reluctant to 'eat their sweets in wrappings', 'bathe with raincoats', 'sacrifice pleasure for something as obvious as death', or be convinced that AIDS is anything more than an 'American Invention Discouraging Sex'. Bickering, misconceptions and myths have not disappeared with alarmism, and accelerated consumerism is yet to be made a key part of the HIV/AIDS equation. Commenting on the situation in Harare after reading a draft of this paper, a female scholar in her thirties at the University of Zimbabwe said: 'The sad thing is such wealthy men buy antiretrovirals, while the women die and the statistics are testimony to this. It is strange that women my age, educated, some with two degrees, including US MBAs, can allow themselves to be domesticated this easily, simply because the men earn more and are ready to spray them with gifts.'

Her concern is legitimate not only for understanding the realities and illusions of gender struggles among the educated women of the continent but also for dealing with the fact that more women than men are affected by HIV/AIDS. If the educated and better off have chosen to sacrifice their agency in the interest of what James Ferguson (1999: 166-206) has termed 'expectations of domesticity', the most vulnerable are still in their dependent teens and twenties and, as such, 'have a much higher chance of being infected than men of the same age, because they are sleeping with older men, who tend to have more money', and who tend to prefer naked love to love in gloves. And if male and female rates equalize in the mid-thirties, it is because 'the women who caught it young die, and men get old and prosperous enough to start supporting younger mistresses' ${ }^{48}$ Whether one is disquette, thiof or

\footnotetext{
${ }^{47}$ At the Universite Omar Bongo de Libreville, students and staff talk both of 'moyennes sexuellement transmissibles' ('sexually transmitted marks') and 'moyens sexuellement transmissibles' ('sexually transmitted property') (cf. Mbah and Soumaho 1996).

${ }^{48}$ The Economist, 17 January 2004, p.11.
} 
whichever metaphor of choice, there is a pressing need to address the fact that consumer sex is lethal sex, as 'graveyards are expanding in all directions, and tombs are overrun with weeds because the living are too weak to tend them', ${ }^{49}$ or too busy at other funerals. There is need as well, to address the poverty that makes consumer sex so tempting.

Much remains to be known about the sexual networks that have given HIV/AIDS reason to celebrate in Africa. As Adebayo Olukoshi and I have argued:

the need for more creative social science research is all the more urgent, given that the limited evidence available on the impact and trajectory of the pandemic points to a variety of shifts in relations of power and production, and in the arenas of politics and culture. A careful study of such changes is also justified by prospects for the formulation of more relevant policies to improve the capacity of individuals, families, communities and governments to respond to the challenges of managing different aspects of the disease. [Olukoshi and Nyamnjoh 2003: 1]

It is therefore hoped that these introductory observations on the language of consumerism, the commoditization of sex and sexified commodities in Dakar are able to generate research interests and debate on such themes as phallocracy, poverty, consumerism, commoditization of persons and bodies, and the concomitant fatalism in Africans that is preyed upon by opportunism of all sorts. Through such research, we might just obtain better insights into the dynamics of persistent gender inequalities and the challenges and paradoxes of HIV/AIDS in Africa.

\section{REFERENCES}

ADB (African Development Bank). 2003. Selected Statistics on African Countries. Vol. 22. Tunis: African Development Bank.

Apter, Andrew. 1999. 'IBB=419: Nigerian democracy and the politics of illusion', in John L. and Jean Comaroff, (eds), Civil Society and the Political Imagination in Africa: critical perspectives. Chicago IL: University of Chicago Press.

Arnfred, Signe. 2004a. 'Introduction', in Signe Arnfred (ed.), Re-thinking Sexualities in Africa. Uppsala: Nordiska Afrikainstitutet.

Arnfred, Signe (ed.). 2004b. Re-thinking Sexualities in Africa. Uppsala: Nordiska Afrikainstitutet.

Bayart, Jean-François, Stephen Ellis, and Béatrice Hibou. 1999. The Criminalization of the State in Africa. Trans. by Stephen Ellis. Oxford: James Currey; Bloomington: Indiana University Press. (1997. La Criminalisation de l'Etat en Afrique. Bruxelles: Editions complexe.)

Biaya, Tshikala Kayembe. 1999a. 'Hair statements in urban Africa: the Beauty, the Mystic and the Madman', CODESRIA Bulletin 1, 2: 32-38.

$1999 \mathrm{~b}$. 'Eroticism and sexuality in Africa: directions and illusions', CODESRIA Bulletin 3, 4: 41-46.

49 The Economist, 17 January 2004, p.10. 
2001. 'Les plaisirs de la ville: masculinité, sexualité et féminité à Dakar (1997-2000)', African Studies Review 44 (2): 71-85.

Buggenhagen, Beth Anne. 2003. 'At Home in the Black Atlantic: circulation, domesticity and value in the Senegalese Murid trade diaspora'. Ph.D. thesis. University of Chicago.

Chomsky, Noam. 1999. Profit Over People: neoliberalism and global order. New York: Seven Stories Press.

Cole, Jennifer. 2004a. 'The Jaombilo of Toamasina (Madagascar): globalization, agency and the transformation of youthful gender relations'. Paper presented at Childhood and Globalization Conference, 19-21 March, George Mason University.

-2004b. 'Fresh contact in Tamatave, Madagascar: sex, money, and intergenerational Transformation', American Ethnologist 31 (4).

Comaroff, Jean, and John Comaroff. 1999. 'Alien-nation: zombies, immigrants and millennial capitalism', CODESRIA Bulletin 3, 4: 17-28.

2000. 'Millennial capitalism: first thoughts on a second coming', Public Culture 12 (2): 291-343.

de Jong, Ferdinand. 2004. 'The social life of secrets', in Wim van Binsbergen and Rijk van Dijk (eds), Situating Globality: African agency in the appropriation of global culture. Leiden and Boston: Brill.

Diamani, Jean-Pierre. 1995. 'L'Humour politique au Phare du Zaire', Politique Africaine 58 (juin): 151-157.

Dilley, Roy. 2004. 'Global connections, local ruptures: the case of Islam in Senegal', in Wim van Binsbergen and Rijk van Dijk (eds), Situating Globality: African agency in the appropriation of global culture. Leiden and Boston: Brill.

Ferguson, James. 1999. Expectations of Modernity: myths and meanings of urban life on the Zambian Copperbelt. Berkeley: University of California Press.

Gemmeke, Amber Babke. 2002. 'Marabout women in Dakar: rural healers and Islam in an urban context'. Research proposal. CNWS, University of Leiden.

Gologo, Habibatou. 2003. 'C'est la saison des rondeurs ... vivent les fesses', Thiof 7: 27-29.

Haram, Liv. 2004. "“Prostitutes" or modern women? Negotiating respectability in northern Tanzania', in Signe Arnfred (ed.), Re-thinking Sexualities in Africa. Uppsala: Nordiska Afrikainstitutet.

Hope, Kempe Ronald, and Bornwell C. Chikulo (eds). 2000. Corruption and Development in Africa: lessons from country case-studies. Basingstoke: Macmillan; New York: Palgrave.

Ly, Abdoulaye. 1999. 'Brief notes on eroticism among the Lawbe, Senegal', CODESRIA Bulletin 3, 4: 46-48.

Malaquais, Dominique. 2001. 'Arts de feyre au Cameroun', Politique africaine 82 (juin): 101-118.

Masquelier, Adeline. 2004. 'How is a girl to marry without a bed? Weddings, wealth and women's value in an Islamic town of Niger', in Wim van Binsbergen and Rijk van Dijk (eds), Situating Globality: African agency in the appropriation of global culture. Leiden and Boston: Brill.

Mbah, Jean-Ferdinand, and Mesmin-Noël Soumaho. 1996. La Question du mariage en milieu universitaire au Gabon. Libreville: CERGEP/Les Editions Udégiennes.

Mbaku, John Mukum. 2004. 'Fighting poverty and deprivation in Africa: the continuing struggle', in John Mukum Mbaku and Suresh Chandra Saxena (eds), Africa at the Crossroads: Between Regionalism and Globalization. Westport CT: Praeger.

Mbaku, John Mukum, and Suresh Chandra Saxena (eds). 2004. Africa at the Crossroads: between regionalism and globalization. Westport CT: Praeger. 
Mbembe, Achille. 1985. Les feunes et l'ordre politique en Afrique noire. Paris: L'Harmattan.

1992. 'Provisional notes on the postcolony', Africa 62 (1): 3-37.

2001. On the Postcolony. Berkeley: University of California Press.

Menthong, Hélène-Laure. 2000. 'Les cadres masculins de l'expérience féminine. Les représentations collectives des garçons sur les filles et leurs trajectoires scolaires', in Luc Sindjoun (ed.), La Biographie sociale du sexe. Genre, société et politique au Cameroun. Paris: Karthala; Dakar: CODESRIA.

Moore, Henrietta L., and Todd Sanders (eds). 2001. Magical Interpretations, Material Realities: modernity, witchcraft and the occult in postcolonial Africa. London: Routledge.

Morris, Alan, and Antoine Bouillon (eds). 2001. African Immigration to South Africa: francophone migrants of the 1990s. Pretoria: Protea/IFAS.

Moutome Ekambi, Jacqueline. 2003. 'Les étudiants: la vie, l'amour, et les études', African Studies Review 46 (2): 37-60.

Nlandu-Tsasa, Cornelis. 1997. La Rumeur au Zaire de Mobutu. Radio-trottoir à Kinshasa. Paris: L'Harmattan.

Nyamnjoh, Francis B. 2001. 'Delusions of development and the enrichment of witchcraft discourses in Cameroon', in Henrietta L. Moore and Todd Sanders (eds), Magical Interpretations, Material Realities: modernity, witchcraft and the occult in postcolonial Africa. London: Routledge.

-2002. 'Children, media and globalisation: a research agenda for Africa', in Cecilia von Feilitzen and Ulla Carlsson (eds), Children, Young People and Media Globalisation. Yearbook 1651-6028. Göteborg: UNESCO International Clearinghouse on Children, Youth and Media (NORDICOM, Göteborg University).

2003. 'Globalization, boundaries, and livelihoods: perspectives on Africa', Philosophia Africana 6 (2): 1-18.

2004. 'Globalization and popular disenchantment in Africa', in John Mukum Mbaku and Suresh Chandra Saxena (eds), Africa at the Crossroads: between regionalism and globalization. Westport CT: Praeger.

Nyamnjoh, Francis B., and Ben Page. 2002. 'Whiteman Kontri and the enduring allure of modernity among Cameroonian youth', African Affairs 101 (405): $607-634$.

Nzongola-Ntalaja, Georges. 2002. The Congo from Leopold to Kabila: a people's history. London: Zed.

Okeke, Philomina. 1998. 'The First Lady syndrome: the (en)gendering of bureaucratic corruption in Nigeria', CODESRIA Bulletin 3, 4: 16-19.

Olukoshi, Adebayo, and Francis B. Nyamnjoh. 2003. 'Editorial', CODESRIA Bulletin 2, 3, 4: 1 .

Sekoni, Ropo. 1997. 'Politics and urban folklore in Nigeria', in Karin Barber (ed.), Readings in African Popular Culture. London: International African Institute; Oxford: James Currey; Bloomington: Indiana University Press.

Silberschmidt, Margrethe. 1999. 'Women Forget that Men are the Masters': gender antagonism and socio-economic change in Kisii District, Kenya. Uppsala: Nordiska Afrikainstitutet.

The Economist. 17 January 2004. 'How to make Africa smile: a survey of sub-Saharan Africa', pp. 1-16.

Toulabor, Comi M. 1981. 'Jeu de mots, jeu de vilains. Lexique de la dérision politique au Togo', Politique africaine 3 (octobre): 55-71.

van Binsbergen, Wim, and Rijk van Dijk (eds). 2004. Situating Globality: African agency in the appropriation of global culture. Leiden and Boston: Brill. 


\section{ABSTRACT}

This discussion traces metaphors of consumerism, commoditized sex and sexified commodities that proliferate throughout urban Africa, signalling the intensified globalization of images of desire and opportunity, on the one hand, and chronic poverty and destitution, on the other. Focusing on sexual economies in Dakar as a case in point, the paper attempts an analysis of how, in situations of increasing scarcity and transurban articulations, language, sex, possession, loss, self-construction and self-corruption mutually shape each other. The paper seeks to represent the textures and intricacies that arise as the interdependencies among status, pleasure, appropriation, seduction and livelihood are worked out. It examines how these operations themselves elaborate a landscape of possibilities always on the verge of overflowing established sense and sentiments, yet somehow reined in, held, albeit in a highly tenuous relationship, to what is known and valued. The city makes itself urban, despite the nearly impossible economic and political conditions it faces, through a capacity to narrate these tales of fishing (as well as fishy stories), but also always trying to chase, to catch up with its capacity to proliferate words. Written against the background of the threat posed by HIV/AIDS in Africa, the paper also draws attention to the need for further scholarly research on the lethal cocktail of the twin globalization of consumerism and poverty in marginal sites of accumulation pregnant with contradictions and uncertainties such as Africa.

\section{RÉSUMÉ}

La présente analyse vise à rechercher les motivations réelles du consumérisme, du marché du sexe et des relations sexuelles monnayées qui prolifèrent à travers les villes africaines, illustrant ainsi la mondialisation accrue des images de désir et d'ouverture d'une part, ainsi que la pauvreté et la déchéance chroniques d'autre part. En se basant notamment sur l'exemple des économies sexuelles de Dakar, cet exposé essaie d'analyser la manière dont la langue, le sexe, le besoin de jouissance, le chagrin, l'autodétermination et l'auto corruption interfèrent dans un contexte de pénurie grandissante et d'interconnexions urbaines. L'analyse se propose de présenter la structure et les complexités qui naissent de l'interdépendance des facteurs tels que le statut, le plaisir, l'autodétermination, la séduction et les moyens d'existence, tout en examinant la manière dont ces derniers offrent un éventail d'opportunités ayant toujours un lien avec les innombrables idées et sentiments préconçus, mais pourtant refoulés et contenus d'une certaine manière, parfois dans un contexte extrêmement difficile, au regard des normes et valeurs établis. La ville s'urbanise, en dépit de la situation politique et économique inimaginable à laquelle elle fait face, grâce à sa capacité de narrer des histoires de pêche (y compris ces histoires louches), mais aussi de poursuivre et de rattraper son retard dans la création de mots. Le présent exposé, qui a été rédigé dans un contexte où l'Afrique est menacée par la pandémie du VIH/SIDA, pose également le problème de la nécessité de mener des recherches plus savantes sur le danger mortel que représente la mondialisation du consumérisme et de la pauvreté dans des milieux marginalisés et pleins de contradictions tels que l'Afrique. 
Copyright of Africa is the property of Edinburgh University Press. The copyright in an individual article may be maintained by the author in certain cases. Content may not be copied or emailed to multiple sites or posted to a listserv without the copyright holder's express written permission. However, users may print, download, or email articles for individual use. 